\title{
Expected but Permanent? : The Tatmadaw's Continued Political Involvement in Myanmar
}

\author{
Adam P. MacDonald \\ Independent Academic
}

\begin{abstract}
The Tatmadaw remains the most powerful political entity in Myanmar, motivated to preserve four core interests regardless of other changes to the state and society - maintenance of complete institutional autonomy and independence; exclusive control over security portfolios; veto powers over constitutional change; and inhibiting prosecution for actions conducted during the Junta era. These interests are embedded within and supported by a praetorian ethos pillared upon a national security narrative justifying the military's ongoing political involvement while the democratic process continues to mature, including past the upcoming parliamentary elections this November. New institutions and practices, however, have opened the political realm in unprecedented ways. Within this increasingly shifting political landscape, it is uncertain the unity and coherence of the regime- - the military and their retired brethren in charge of the executive and parliament to maintain power, especially due to the large manipulations of the electoral and democratic processes which would be required to ensure their rule. Military intervention cannot be ruled out, but the Tatmadaw is reluctant to overtly and aggressively regain control politically unless it feels its core interests will be irrevocably and immediately compromised by a new government. With their roles and responsibilities protected, the military may feel they can control, or at least marginalize, a parliament and/or government hostile to its interests. The 2015 elections will not, therefore, mark the end of the military's preponderant political influence but continue to erode their control over the pathways of political power and may bring about the first truly civilian-military government in the country's transition away from military rule; a significant milestone as those outside the old, yet still influential, military regime gain access to begrudgingly-ceded power.
\end{abstract}

Keywords: Myanmar, Tatmadaw, elections, power, political roles

\section{Introduction}

Despite the scope and scale of reforms enacted under the Thein Sein government which have dramatically changed many aspects of the state and society, the Tatmadaw (The Myanmar Armed Forces ${ }^{1}$ ) remains the most powerful actor in Myanmar's evolving polity. Constructing a complex system not directly under their control, the Tatmadaw has nonetheless carefully cordoned off special powers, portfolios and positions designed to preserve their core interests. These interests include: complete institutional autonomy not subject to oversight; veto powers over changes to the Constitution; exclusive control over security portfolios; and immunity for

Adam P. MacDonald, independent academic, Halifax, Nova Scotia Canada

${ }^{1}$ The terms Tatmadaw, military and armed forces are used interchangeable to denote the Myanmar Defence Services, unless stated otherwise. 
actions conducted during the Junta era. With the assumption of power by their chosen successors, the Union of Development and Solidarity Party (USDP), the Tatmadaw has largely allowed the political process to operate free from its involvement, save for its constitutionally mandated roles and responsibilities.

Well-founded criticisms regarding the military's intention behind the transition away from direct rule dominated initial analyses of this unfolding phenomenon; but over the years there has been an emerging, but tempered, belief that the Tatmadaw gradually would be conditioned and negotiated into a further and complete political withdrawal. The vetoing of constitutional amendments by military representatives, however, is the most recent example of an institution which appears reluctant to cede, let along negotiate, their political prerogatives anytime soon ${ }^{2}$. With the upcoming November parliamentary elections, furthermore, the military has stated they will remain political actors into the indefinite future. Senior military leaders have, though, repeatedly emphasized their commitment to an eventual withdrawal from the political realm but have refused to place timelines of this process. Such a condition being predicated, according to the generals, on the ability of the new democratic polity to become stable, self-sustainable and capable of defending and promoting the state's national interests - a role the military has historically believed they alone have the capacity to do (Ei Ei Toe Lwin, 2013).

The Tatmadaw remains reluctant to fully return to the barracks, but the political system constructed has opened the political realm in unprecedented ways (whether by design or not), slowing eroding the ability of its original architects to control. As a corollary, this development complicates the traditional characterizations of the Myanmar political landscape as a binary world of democrats and reformers on one side versus the military and their proxies on the other. New institutions, practices and arenas of power and competition have altered the interests, identities and relationships within and between these supposed monolithic and mutually exclusive groupings (MacDonald, 2014). This phenomenon influences, somewhat surprisingly, on the unity of the ruling regime - the military and their retired brethren which control the executive and parliament—with growing differences amongst them further confounding their ability to retain the current governing configuration.

The Tatamdaw, while having a history of reasserting themselves (including violently) directly into politics, appear reluctant to do so at this stage, even with the likely defeat of the USDP in the upcoming parliamentary elections. With their powers protected and constitutionally enshrined, the military may feel they can co-opt, or at least marginalize, a parliament and/or government hostile to its interests. For reformers, especially within the opposition National League for Democracy (NLD), the military continuing to be an influential and necessary actor in politics and governance will have to be accepted. Even with an expected augmentation (perhaps majority) of opposition representatives in the legislature after the November elections, therefore, the promotion of drastic and sweeping changes by the NLD (and/or other actors) against the core interests of the military will most likely motivate an aggressive response, eroding and unraveling the overall prospects of continued reforms. The upcoming elections, nonetheless, may be a watershed moment as those outside the military gain power from a still powerful Tatamdaw. The challenge for reformers will be managing the delicate process of moving the system away from regime maintenance towards regime change without enacting a countervailing reaction

\footnotetext{
${ }^{2}$ Though the parliamentary vote was conducted by secret ballot, the persistent rebuttal by the military leadership to consider constitutional change in the near term and the strong defence by military representatives against any amendments in the debates leading up to the vote strongly suggest the military bloc of parliamentarians voted unanimously to defeat the motion (Kyaw Phyo Tha, 2015).
} 
from those in uniform which still hold significant sway over the future direction of the state.

\section{From Absolute Rules to Veto Players}

The Tatmadaw has been the most durable military regime in the contemporary era, having ruled the state either directly or via tutelage for half a century (Selth, 2013, p. 1). During this time, the military has become not only the most dominant political actor but indeed the nexus of the state, heavily influencing (if not outright controlling) all aspects of the polity and as a result becoming one of the only vehicles of social mobility available to the populace (Steinberg, 2015). The 2011 transfer of power to a new political system not directly under its rule is not the first time the Tatmadaw has pursued such a project; but the opening of the political arena, via a multi-party electoral structure, to those outside the traditional power base is a precedent for a military which has historically closely determined who rules and by what methods. Despite such inclusion (specifically various entities which have for decades been labeled enemies of the state and persecuted by security services), the constitutional stipulations and powers bestowed upon the Tatmadaw cast doubt in many that this transition is nothing more than the institutionalization of military rule in its latest form (Huang, 2013).

Such a characterization is not unfounded or unsubstantiated, but the role of the military has fundamentally changed. From absolute rulers within a closed system under their direct control, the Tatmadaw have become veto players in a pluralistic political landscape in which they do not have exclusive determination of who accesses power, but with entrenched powers necessitating their concurrence on macro-level changes to the state and its political organization (MacDonald, 2013). Politics, for the time being, is no longer the exclusive domain of those in uniform. The military, though, as the architects of the Constitution have conditioned the transfer of power on carving out policy areas under their exclusive control, including portals of influence to ensure the system is not in opposition to their core interests-institutional autonomy; control over security portfolios; a veto over constitutional change; and immunity for past deeds.

As stated in Article 20 of the Constitution ${ }^{3}$, the military is an independent entity not subject to governmental or legislative oversight with the Commander-in-Chief of the Tatmadaw the supreme commander of the armed forces - not the head of state as is common practice in virtually all other countries regardless of regime type. While the head of state, the President, appoints the Commander-in-Chief, this is conditioned on the nomination from and approval by the Nation Defence and Security Council (Article 342), a secretive executive body with large uniform representation. The military, furthermore, has a right to participate in the "National political leadership of the state" (Article 6F) and is charged with safeguarding the Constitution (Article 20F).

In terms of control over security portfolios, the Tatmadaw is responsible for defending the three National Causes: non-disintegration of the Union, non-disintegration of National solidarity, and the perpetuation of sovereignty (Article 20E). Within the execution of these duties, the National Defence and Security Council (NDSC) is the highest executive body charged with overseeing strategic and security issues whose 11 person-membership consists of five active-duty military officers ${ }^{4}$ (Article 201). The Commander-in-Chief of

\footnotetext{
3 All articles cited in this section are sourced from the 2008 Myanmar Constitution. "Constitution of the Republic of the Union of Myanmar". 2008. Ministry of Information.

4 Those members include: The Commander-in-Chief of the Tatmadaw; the Deputy Commander-in-Chief; the Minister of Defence; the Minister of Home Affairs; and the Minister of Border Affairs. The military parliamentary bloc, as well, appoints one of the presidential candidates, which if unsuccessful become one of two Vice-Presidents, who is also a member of the NDSC but not necessarily a military officer.
} 
the Tatmadaw, furthermore, presents a list of nominations for the appointments of the Ministers of Defence, Home Affairs, and Border Affairs which the President must choose from (Article 232Bii), ensuring military representation in cabinet. Chapter 11 of the Constitution, furthermore, outlines a series of sweeping powers which can be bestowed upon the Commander-in-Chief by the President in the event of a declared state of emergency either locally or state-wide. These include complete executive and judicial powers transferred to military authorities (Article 413A) and restricting fundamental rights of the citizenry in the execution of martial law (Article 420).

The Commander-in-Chief is authorized to appoint all military representatives populating their constitutionally guaranteed 25\% seat allocation in the National Parliament (Pyidaungsu Hluttaw) ${ }^{5}$ - comprising of 110 members of the 440 seat House of Representatives (Pyithu Hluttaw) and 56 members of the 224 seat House of Nationalities (Amyotha Hluttaw) (Articles 109 and 141 respectfully). This grants the military an effective veto on constitutional amendments in which most clause changes (including all pertaining to the military) require a 75\% parliamentary approval before a national referendum is conducted (Article 436). The military parliamentary bloc, furthermore, nominates one of the three presidential candidates - which does not need to be an elected representative - to be voted by the Electoral College (comprised of all representatives from the National Parliament) with the two unsuccessful candidates becoming the Vice-Presidents (Article 60Biii).

In terms of shielding its membership - both current and retired-from prosecution, Article 445 specifically prohibits proceedings being taken against members of the former military Junta including the State Law and Order Restoration Council (1988-1997) and the State Peace and Development Council (1997-2011). The President, furthermore, is authorized to grant amnesty to any individual, but in accordance with the recommendation of the NDSC (Article 204). The military, thus, can ensure its broader membership is protected not only for actions committed during the previous regime but as well pertaining to ongoing operations and activities not covered by Article 445 .

These constitutional stipulations enacted demonstrate the careful and surgical cordoning off of reserve domains to the military in order to retain influence over the system at large. With such powers in place, however, the military has largely allowed the executive and legislative branches to run the state and conduct their affairs free from interference. For example, military Members of Parliament (MP) have by in large played a "backbencher" role in the legislature (Egreteau, 2013; Egreteau, 2015a), not enacting any legislation and only being active in debates and voting as a bloc concerning issues which impede on their core interests such as the recent vetoing of constitutional amendments ${ }^{6}$. The willingness of the Tatmadaw to play such a limited role is in part predicated on the assumption of power of their retired brethren in control of the executive and parliament, thereby assuming these new power centers will preserve and promote their interests. Another important aspect of the new political system is that the military has constructed a system pillared on a rules-based framework - the Constitution which increasingly informs and justifies their actions and decisions. The Tatmadaw, therefore, has moved away from ruling via fiat to referring to the Constitution as the final arbitrator of decision-making (Taylor, 2012), having a powerful force on the military which has relented and backtracked

\footnotetext{
${ }^{5}$ All military parliamentarians, thus, are not elected and can be replaced and/or removed solely by the Commander-in-Chief of the Tatmadaw.

${ }^{6}$ Parliament Votes Against Constitutional Reform, Reserves Military Veto.
} 
on a number of issues due to their incongruence with the rules outlined in this document ${ }^{7}$.

The new regime formed, while largely maintaining the continuity of personalities running the state from the Junta era, is more diffused and dispersed across a number of organizations and arenas vice the era of direct military rule. It is more accurate, furthermore, to classify the post-2011 Myanmar political system as an electoral authoritarian regime-specifically due to introduction of new processes and pathways to accessing and wielding power, namely elections. Widespread and comprehensive undermining of recently introduced democratic structures, though, have ensured the preservation of the regime, including the special prerogatives of the military as being a major power in the political architecture (Schedler, 2013; MacDonald, 2013a). While these institutions, furthermore, could be dismantled or dismissed by the Tatmadaw as demonstrated in the past, currently it is within these new venues that power is controlled and contested vice within the military itself.

The intents of the original architects of this system transformation remain unknown and debated but largely residing within two broad categories - those endogenous to the military (including personal interests, corporate interests, and issues of cohesion) and those exogenous (such as the civil sphere, internal security and external security) (Brünte, 2011, p. 10). Externally, most arguments focus on the military's growing concern that international isolationism and sanctions were becoming national security crises due to their increasing overreliance on China as their only meaningful large diplomatic partner (Myanmar's Military, 2014, p. 2); Bertil Lintner, furthermore, assert he has seen internal military documentation indicating such perceptions. Naypyitaw's relationship with Beijing, specifically, not only threatened Myanmar's historic non-aligned and neutralist oriented foreign policy but straightjacketed the state's independence and ability to promote their interests with virtually no other major powers to counterbalance the preponderant influence of China in their foreign engagement portfolio (Lintner, 2013). Constructing a political system which was palatable to international partners, specifically the US and the West, to rebalance their foreign engagements, thus, was a major factor. Other arguments focus on the cessation of most ethnic conflicts in the 2000s leading the military to feel comfortable in selectively transferring power without threatening the breakup of the state, a plan they have attempted to implement for decades (Jones, 2014a). Internally, arguments include governance fatigue on the part of the generals and/or an acceptance of their inability to economically manage the state and a need to relinquish such control to others but within a system where they maintained a predominant role, especially over national security affairs (Brünte, 2011). Elite-brokering and power-sharing, also, may have been a factor in constructing a highly complicated system of multiple power-centers to satisfy the ambitions of various powerful elites as well as co-opting others which were emerging in other areas outside the military realm (Croissant \& Kamerling, 2013; Nyein, 2009).

The most important fact to keep in mind is that retired Senior-General and former President Than Shwe completely oversaw and directed the entire transition process, including positioning subordinate commanders into new roles, before retiring along with his deputy and second in command Vice Senior-General Maung Aye (Hlaing, 2012). Neither has ever explained their decision to move away from direct military rule or any specifics pertaining to the new system enacted. The dispersion of many different power centers in the new configuration may be an attempt to inhibit the rise of a Big Man, an all-powerful centralizing figure (a phenomenon which has been endemic in Myanmar politics since independence) (Hlaing, 2008) who could

\footnotetext{
${ }^{7}$ For example, when the military-nominated Vice President Tin Aung Myint Oo resigned in 2012, the Tatmadaw attempted to nominate former general Myint Swe as his replacement but he was ineligible due to failing to meet the criteria of the position as listed in Article 59. Vice-Admiral Nyan Tun was ultimately chosen as the successor (Barta, 2012).
} 
move against the retired generals and their patrimonial networks as was the fate of former President and General Ne Win at the hands of Than Shwe himself (Hlaing, 2012, p. 3; Steinberg, 2013, p. 152). Motivations and intents remain shrouded in mystery, but it is important to recognize that this process has been a military-led, top down affair in which the generals' hands were not forced due to external invasion, intra-military factionalism or defeat in civil war (Callaham, 2012, p. 120).

\section{The Praetorian Ethos and the National Security Narrative}

A persistent feature of the Tatmadaw's involvement and control over the political apparatus has been a guiding praetorian ethos informing successive generations of officers that the military is the only institution capable of defending and promoting the country's national interests from threats both external and within (Egreteau \& Jagan, 2013). Such a guiding logic and persona was forged and consolidated during the initial decades after independence when numerous ethnic insurgencies and communist defections created the real possibility that the military and the state would collapse (Min, 2008; Myanmar's Military, 2014, p. 3). During this time, furthermore, those in uniform became pessimistic and doubtful of the civilian political leadership's ability to promote the interests of the state over their own idiosyncratic aspirations. As a result, the military has built and entrenched within its membership a sense of guardianship over protecting the state, moving beyond developing competencies in warfare to controlling the political levers of power itself. This sense of guardianship was enshrined in the concept of the three "National Causes"-non-disintegration of the Union, non-disintegration of National solidarity, and perpetuation of sovereignty-outlining the fundamental (and non-negotiable) objectives the Tatmadaw will defend.

Externally, Myanmar has not faced a direct foreign threat to its survival since independence, but the impact of extensive sanctions and diplomatic isolation imposed on the state following the 1988 coup increasingly became a security threat for the generals. Such apprehension was magnified during the presidency of George W. Bush, whose tough stance and actions against pariah and rogue regimes (including Myanmar being labelled an "Outpost of Tyranny") worried the Tatmadaw leadership that they could be militarily targeted; to the extent, furthermore, that the decision to move the capital to Naypyitaw in 2005 was motivated in part by such concerns (Charney, 2009, p. 195). Developing political and military relations with North Korea (after the cessation of diplomatic contact for nearly two decades following the assassination attempt of the South Korean president by North Korean agents in Rangoon in 1983) drew the ire of the international community, specifically reports of possible cooperation regarding nuclear weapons technology (Ahn, 2010). The resumption of relations between these two pariah states was not unusual given their international isolation and common concern about being targeted by the West, with the focus of the relationship on military technologies including ballistic missiles, underground bunkers and perhaps nuclear weapons indicating regime survival was the primary motivation of the Tatmadaw's re-engagement with Pyongyang. Since the transfer of power in 2011, however, foreign relations, specifically with the West, have improved significantly. This is largely are function of reforms enacted by the Thein Sein government and repeated guarantees by Naypyitaw of terminating all relations with North Korea, though suspicions remain (MacDonald, 2013a). This has led to the cessation of most sanctions (save for military related industries, arms sales and individuals accused of human rights abuses) and inclusion back into the international community. With the amelioration of relations with the West (the perceived greatest external threat of the military Junta), Myanmar once again resides within an international and regional context where there are no overarching external threats to the government's or state's legitimacy 
and survival.

Internally, ethnic conflict remains but on a scale and intensity far removed from the early decades of Myanmar's existence when there was the real possibility of state disintegration. While still presenting challenges to the safety and security of the state, these conflicts are largely employed as rationales for larger, more institutional interests of the Tatmadaw to remain politically powerful and incubated against oversight. The national security narrative, as a result, commonly espoused by the military leadership has fused the corporate interests of the institution with the supposed national interests of the state to the degree to which they have become indistinguishable (Than, 2012).

The military over the years has employed a successful divide and rule strategy with respect to ethnic armed groups, inhibiting the development of a comprehensive and simultaneous challenge from all fronts (Smith, 2015). Over the past four decades, furthermore, there has been a continuously changing mosaic of ceasefires and renewed fighting with various ethnic armed militias which question the commitment of the military towards national reconciliation via the National Ceasefire Accord. Signing of ceasefires, also, has in large part has been predicated on co-opting local elites with lucrative business and resource contracts which create social frictions within these groups, with the vast majority of the population accruing little benefit from these deals. A phenomenon Mary Callaham has termed "emerging political complexes"-a flexible and highly changing conglomeration of military officers, local officials, government representatives and domestic and foreign investors to monopolize certain industries to the exclusion of the wider public (Callaham, 2007).

Ensuring these conflicts do not become unmanageable, the military uses such tensions to justify their continued political preponderance as well as supporting the maintenance of an oversized security sector and wide-spread emergency powers. Within these disputed areas, furthermore, the military maintains a monopoly over certain extractive resources, such as jade and rubies (Marshall \& Min, 2013). Ethnic conflicts, therefore, substantiates large military budgets; procurements of war fighting equipment; political involvement at both the national and state level; war profiteering due to control of natural resources; and ultimately a portal of intervention or outright overthrow of the political system in the name of national security (Walton, 2015). Ethnic reconciliation is not anathema to the military per se, but highly conditioned on ensuring its economic interests are protected; its membership do not face prosecution for actions conducted during these conflicts; and securing the Tatmadaw's undisputed role as the guardian and protector of the state. Issues most ethnic militias and political groups oppose and assert need addressing (and compromise) to move the relationship forward.

Communal violence between Buddhists and Muslims is another contentious issue with ramifications to the security and integrity of the state. While not a new issue for Myanmar, the 2012 outbreak of violence between Burman Buddhists and Rohingya Muslims in Rakhine State was originally characterized as a local phenomenon; but with the spreading of anti-Muslim violence throughout the rest of the country it became obvious this is a national level matter showcasing deep social and religious cleavages (Walton, 2015). The rise of Buddhist nationalism, in particular, since the transition era began in 2011 has become a major (and unsettling) feature of Myanmar's political and social landscape (Steinberg, 2014). Amongst some Buddhists, furthermore, there is a sense of unity and interdependence between Buddhism, the state and the majority ethnic group - the Burman. With the inclusion of ethnic representation into mainstream politics, and the widening of the social and economic spheres to other non-Burman, non-Budhdist entities, there are some within the Buddhist community which feel their privileged position within the state is at risk, specifically at the hands of Muslims (Nilsen, 2015). Anti-Muslim rhetoric and calls for action, furthermore, by Buddhist nationalists has transformed over 
the years from social mobilization (such as the 969 movement pressuring the population to avoid Muslim owned business) to pseudo-political lobbying groups, the most prominent of which is the Organization for the Protection of Race, Religion and Belief (also known as Ma Ba Tha) (Walton, 2015, p. 125). This has come to the forefront of the political discourse via the passing in parliament of a series of bills regarding race and religion, lobbied for by $\mathrm{Ma} \mathrm{Ba} \mathrm{Tha,} \mathrm{drawing} \mathrm{concerns} \mathrm{they} \mathrm{could} \mathrm{institutionalize} \mathrm{social} \mathrm{divides} \mathrm{and} \mathrm{tensions,}$ specifically marginalizing Muslims and women in general (Nilsen, 2015).

The military has kept its distance with respect to the issues of communal violence but has made it clear that instability will not be tolerated. The commander of the Tatmadaw, Senior-General Min Aung Hlaing, however, has carefully stated that the military would only intervene, including taking over the political process if necessary, on the orders of the President (Channel News Asia, 2015). The Chairman of the Electoral Commission, himself a former general and ex-USDP MP, has also warned recently that internal violence, specifically leading up to the election, may necessitate the military's return to power to ensure stability (Nan Lwin Hnin Pwint \& Zu Zu, 2014). The military has avoided both politically commenting on the matter as well as transferring primary responsibility to tackling social unrest (not ethnic conflict) to the Myanmar Police Force (MPF), a 72,000 strong organization tasked with a wide range of responsibilities regarding internal security. While the MPF undergoes a much needed revamp in terms of numbers, recruiting, acquisition of non-lethal weapons and training for new missions and mandates, they remain a subordinate security service to the Tatamdaw.

Recent police brutality against protestors in Yangon and student demonstrators in Letpadaung, as well, demonstrate not only the lack of effective training and weaponry to deal with such matters but are indicative of a force which is still by and large removed from society. Military commanders, as well, view the MPF as a strategic reserve to augment the military when needed and organizationally the MPF falls under the Ministry of Home Affairs which is headed by an active general appointed by the Commander-in-Chief (Martson \& Morgan, 2015). There are, furthermore, a number of military officers transferring to the MPF as a new source of power and influence which further complicates the ability of the organization to become institutionally independent from the Tatmadaw (Selth, 2013). Along with the intelligence services, the MPF, while given greater latitude to pursue their primary duties, remains a subordinate security service to the military and will most likely continue to support their endeavors, including politically (Selth, 2015).

The current security situation within Myanmar, apart from its external environment, largely remains the same as it was during the era of direct rule but with some important differences. First, while ethnic conflict continues, specifically in Kachin and Shan States, there is a committed government push has secured a state-wide cease fire accord,followed by national reconciliation efforts to meaningfully include ethnic groups within the larger polity. Second, the growing impact and importance of outstanding ethnic conflict and communal violence to political leaders highlights an issue which while not driven or motivated by the military could be used as a context for their resumption of power. A number of state of emergencies have been declared in areas as a result of such conflicts, most recently the Kokang region, but they have been local in nature with no indication the military presently feels any issue threatens the entirety of the state. It is inaccurate to completely blame the military (and the wider security sector ${ }^{8}$ ) for either encouraging or permitting these social tensions to assume a violent form, but their sincerity towards real concrete measures to marginalize and

\footnotetext{
${ }^{8}$ During the 2012 anti-Rohingya violence which engulfed Rakhine state, however, the inaction of the MPF demonstrated a level of concurrence and sympathy with Burman Buddhists conducting the violence (Selth, 2013, p. 22).
} 
eventually overcome these matters is highly questionable. For example, issues of a federated army (something of significant importance to many ethnic groups), decentralization of powers (potentially to include the creation of a federal state), and granting citizenry and protection for the Rohingya and wider Muslim population are matters the military may not be willing to support presently. With that in mind, however, Myanmar's two other main political entities - the USDP and the NLD which are also heavily ethnically Burman, have not clearly stated their plans to ameliorate ethnic and social conflict either. There is, therefore, a high likelihood of violence in and around the upcoming election (Nilsen \& Tønnesson, 2014), especially if ethnic groups feel they are being marginalized in the political and ceasefire processes combined with risks surrounding communal violence as some Buddhist monks ramp up their opposition to other religious groups.

\section{Regime Solidarity in Question}

Communal violence and ethnic conflict have become divisive matters not just across society and the political spectrum but as well between the main actors comprising the current regime - the military, the USDP dominated parliament and the Thein Sein government. One of a few but growing areas of dispute and disagreement (though not open conflict) between these three entities which challenges earlier assumptions regarding their cohesiveness, unity, and ultimately adherence to the wishes of the generals. Due to the distribution of active and retired military officers in the new political architecture, it initially appeared that the military would still be largely determining policy via close patrimonial and personal links to many recently retired generals assuming these new positions.

A number of prominent figures from the previous regime, the State Peace and Development Council (SPDC), populate the highest ranks of all major centers of powers in Myanmar including: Senior-General Min Aung Hlaing as the handpicked successor to lead the Tatmadaw by Than Shwe; President Thein Sein, former SPDC Prime Minister; and Thura Shwe Mann, the former third ranked general in the SPDC, as Speaker of the House of Peoples (Pyithu Hluttaw). A number of other senior military officers retired prior to the 2010 elections to comprise the upper ranks of the newly formed USDP, ensuring the leadership was former military. Thein Sein's original cabinet, also, consisted of 26 active or retired military officers with only four civilians (Than, 2014, p. 95). The Union Election Commission, as well, is headed by a former military general with the majority of the council having military backgrounds (Activists Call for Replacement of Election Commission Members, 2015). Such a configuration, thus, was largely seen as military in membership and mindset. As the political system continues to evolve, however, new arenas of power have altered actors' identities, interests and relationships with one another in quite pronounced ways. This is most evident (but not exclusively so) in the relationships between the main power brokers in Myanmar, which faced with the real prospect of a comprehensive USDP defeat in the upcoming elections would require large-scale voting manipulations and/or military intervention as the only real options to resist regime change (MacDonald, 2015). Confronting such prospects, small divisions and rivalries emerging within the regime leadership highlight the different, and at times conflicting, power bases that have developed in this more diversified ensemble of actors and organizations vice the era of direct military rule.

The USDP and the military have diverged on a number of policy issues within parliament. For the Tatmadaw, as an unelected body, resisting constitutional change to guarantee their continued powers and prerogatives have largely motivated their MPs' behavior within debates and voting patterns. For the USDP, moreover, their access and maintenance of political power depends on their electoral palatability to the public, 
especially as it appears the government and Electoral Commission are committed to holding free and fair elections. The USDP is concerned they remain too closely associated with the military, acting as simply proxies for the generals vice being an autonomous political entity with their own interests and policy positions. With respect to the recent constitutional amendment vote, if we assume the military voted as a bloc this would imply almost $90 \%$ of elected representatives voted for the bill, which would have included a large swath of USDP MPs which comprise over half the seats in parliament (Kyaw Phyo Tha, 2015). The USDP leadership, furthermore, in charge of the Parliament may have been motivated to bring constitutional amendments to a vote to force the military MP bloc to veto the motion, allowing the USDP to portray the lack of constitutional reform rests squarely on the Tatmadaw. Another area where one would expect to find mutual support was the USDP's promotion of a Proportional Representation electoral system to replace the currently used First-Past-The-Post one. Even if the NLD wins the upcoming elections, distributing seats based on voting share vice a plurality victory per constituency would largely benefit the USDP as they would be rewarded for total vote share, ensuring a bloc of seats whereas no guarantee exists under the current First-Past-The-Post System which is prone to large distortions between popular vote and seats won (Martson, 2015). Military MPs, however, along with the other major parties voted against the motion, citing it would have been in violation of the Constitution (Myint, 2014).

Tensions are evident, also, in the military's relationship with the Thein Sein government. Complex ground and air campaigns with the resumption of fighting against the Kachin Independence Army in 2013 by the Tatmadaw appears to have been in contravention to direction given by President Thein Sein to minimize the conflict and show restraint (Lintner, 2013). Ongoing operations in Shan State, including a state of emergency declared in the Kokang region, have also showed a military command largely operating under its own auspicious with little government oversight or direction despite the fact these activities have larger political and foreign relations implications. Kachin and Shan States, for example, border China which is concerned about the violence along its periphery, specifically in light of the deaths of five Chinese farmers from an aircraft bomb which accidently landed on Chinese soil. These large scale operations, as well, complicate attempts to portray these matters as lead by rogue commanders going outside their mandates but rather a complex plan which necessitated awareness and most likely concurrence from the highest levels in the military (Martson \& Morgan, 2015). Much of the confusion regarding authority to conduct borderland engagements, furthermore, stems from the complicated relationship between the President and the Commander-in-Chief of the Tatmadaw who is the supreme commander of the armed forces. Under this divide, the military is operating within its constitutional purview but is creating tensions and stresses in the executive to ensure these plans are commensurate within their larger governance agenda and strategy.

Alongside these organizational tensions, political posturing by the regime's most senior figures-Senior-General Min Aung Hlaing, President Thein Sein and Lower House Speaker Thura Shwe Mann - to position themselves to best capitalize on the expected transformation of the country's political landscape leading up to and following the November elections has led to growing, and in some cases public, frictions between them. First, there are indications that Senior-General Min Aung Hlaing will retire and possibly may be nominated by the military MP bloc as their presidential candidate (who does not need to be an elected official). Min Aung Hlaing is popular amongst the senior military leadership as someone who will defend the military's interests at the highest level of government (Aung, 2015). There are ongoing disagreements reports suggest, also, between the Commander-in-Chief and President Thein Sein over the pace 
and nature of the ceasefire process with the latter securing a conclusion before the election but the former concerned the process is moving too quickly (Nguyen, 2015). Min Aung Hlaing, as well, represents a segment of the Tatmadaw concerned that Thura Shwe Mann is distancing himself from the military in an attempt to become more electorally desirable to voting populations (Barany, 2015, p. 89). Thura Shwe Mann, specifically, has attached his political credentials on mobilizing the entire parliament (including the USDP) as the Speaker of the Lower House into a unified check against executive power, leading to a number of disputes with President Thein Sein and his cabinet which are by in large ex-UDSP MPs and military officers (Not a rubber stamp, 2013, p. 6). Thura Shwe Mann has expressed his desire to run for President and had publicly stated President Thein Sein will not seek a second term, drawing rebuke from the President's office.

Leadership disputes reached a dramatic climax in August when security forces surrounded the USDP headquarters as part of a coordinated effort to force Thura Shwe Mann to resign as party leader (a position he secured in July) along with a number of his associates populating key roles in the party hierarchy. Though Thura Shwe Mann remains a USDP member and Speaker of the Lower House, his purging appears to have been orchestrated by both the military and the Thein Sein government, especially as a number of the President's key allies have fulfilled these newly-vacated positions. To what extent, however, this internal party coup was actually led by the President, or whether the military simply used his office as a declaratory justification, the removal of Thura Shwe Mann seriously challenges the purported separation of the USDP from Tatmadaw influence. One of the suggested reasons for Thrua Shwe Mann's withdrawal, also, is the fact that he denied over two-thirds of former military members' candidacies for the upcoming election, with the military leadership feeling he was distancing the USDP from the Tatmadaw to an unacceptable degree (Kuok, 2015). The use of security forces to coerce leadership changes in a private political party, also, harkens back to the era of direct military rule with the generals feeling no inhibition to overtly intervene when deemed necessary. For the USDP, also, such measures damage their already difficult public image, with these latest events contributing to the commonly held narrative that they are simply a surrogate politically for those in uniform. The purge, also, is but the latest in a series of power struggles amongst military generals and opens questions pertaining to the exact relationship between President Thein Sein and Senior-General Min Aung Hlaing in terms of decision-making pertaining to such sensitive matters.

Despite these tensions, both the military leadership and President Thein Sein have recently stated that the Tatmadaw will remain politically involved into the foreseeable future (Fisher, 2015). Thura Shwe Mann, as well, despite his reformist image has warned against constitutional change before the election due to its potential destabilizing effect on the country (Lwin, 2014), implicitly acknowledging and supporting the Tatmadaw's role as a political actor. Whether such a position has changed now with his demotion, but not expulsion, from the USDP remains uncertain. The emerging power competitions between the leadership of the regime, furthermore, are not unusual neither for Myanmar in general or the military in particular which has seen numerous power struggles within its ranks. These disputes, nonetheless, erode and complicate attempts to develop institutions and processes that can withstand and outlive reigns of personalist leaders which have relied upon patrimonialism and patron-client relations to rule the state (Hlaing, 2008). What is different in the current context is where power was once concentrated within the military community, the upcoming elections may be a watershed moment in which the current regime configuration is defeated and replaced in part by those which have traditionally been denied access to power. While the military will retain its position, the nature and disposition of the new parliament, and the future of the USDP, will have large ramifications for the political 
landscape and the entire country.

\section{The 2015 Elections and Beyond}

Unlike the highly flawed 2010 elections which ushered in the military-backed USDP into the legislature, the Thein Sein government and Union Election Commission appear committed to hosting free and fair elections in November. In particular, a number of areas of manipulation during the 2010 contest have seen significant amendments including updating voter lists, better control of advanced ballots, and inviting foreign observers (including from the EU and Carter Foundation) to oversee the election (Myanmar's Electoral Landscape, 2015; Reuters, 2015). Guaranteeing free, fair and transparent elections is an important endeavor, but just as critical is ensuring the military ultimately accepts the final results. While the ruling USDP may utilize a number of measures to manipulate the electoral process as in 2010, the Tatmadaw has the ability, as demonstrated in the past, to reintroduce themselves directly, overthrow the system (even one run by their allies) and rule by fiat with politics once again becoming the exclusive purview of those in uniform. The military, thus, is the "wild card" in this delicate period in Myanmar's evolving polity (Nguyen, 2015) - their intentions and actions leading up to and during the election will be the decisive factor determining if the transition process is allowed to proceed.

While the beginning of the transition period was highly scripted and organized by the outgoing ruling Junta, over the years these new arenas of political power have taken a life of their own and begun operating largely independently (Pederson, 2011). The legislature, in particular, has proven to not simply be a rubber stamp parliament but a body dedicated to keeping the executive branch accountable, producing a number of unique voting patterns between apparently hostile parties (Egreteau, 2015b; Kean, 2013; Not a rubber stamp, 2013). Amongst this shifting landscape, if elections are conducted in a fair and transparent process the USDP does not just face electoral defeat but political annihilation at the hands of the hugely popular NLD in the central, Burman divisions and a variety of well-organized ethnic parties in the border states. Despite the advantages of incumbency with vast party offices, experience in parliament and government, and large resources to help broaden their voter base throughout the country, such efforts will most likely not inhibit losing significant amounts of seats as they are seen as too closely affiliated with the old regime. Facing the prospect of the marginalization of the USDP in the legislature to potential obscurity, therefore, it is unclear what alterations in the current power configuration would be palatable to the military in the upcoming elections.

It is not clear the willingness of the Tatmadaw to intervene to prop up the USDP, especially if the generals feel their mandated powers and influence would be enough to tame and co-opt a possible legislature and/or government largely compromised of those hostile to its interests. The military will retain significant representation in parliament, cabinet and be a critical player in the determination of the presidency. Most importantly, while the NLD may win a majority of seats in the legislature, the president (who then nominates the cabinet which does not be comprised of elected representatives) is not directly elected in a national vote but by an Electoral College in which the military has a significant vote share and right to nominate one of the three candidates. The NLD, therefore, even with a large electoral mandate will most likely have to negotiate with the generals, the USDP and other parties in terms of inclusion into the executive and government. In light of this future, some key pivotal USDP leaders (and former military officers) may be positioning themselves as an ideal coalition partner, developing ties through a shared reformist agenda with the possibly dominate NLD in the 
legislature while massaging the concerns of the military about changes to its power and roles. If Aung San Suu Kyi, furthermore, remains barred from being nominated as a presidential candidate (specifically due to Article 59F), the Speaker of the Lower House Thura Shwe Mann, despite his removal from the USDP leadership, may be seen as a satisfactory candidate to both sides to form government.

Ethnic and communal violence threaten to disrupt if not entirely shutdown the electoral process, with the incumbents the main benefactor from any sort of delay or disruption. It is important to note, as well, the unique political configurations forming between supposed adversaries. For example, a number of prominent monks, a community targeted by the military Junta in the 2007 Saffron Revolution, have publicly lobbied ${ }^{9}$ that the USDP, largely comprised of former military officers from the Junta era, retain power to provide stability and ensure Buddhism's place of privilege (Weng, 2015). Opposition to military rule, also, is not a unified and cohesive entity but one with a host of other divisions along urban-rural, ethnic and socio-economic lines (Barany, 2015, p. 98); cleavages that may be exploited by those in power to further divide the cohesiveness and political action of those opposed to its rule. Despite these concerns, however, the most likely result of the November elections (if free and fair) is a large plurality and possibly a majority in the legislature for the NLD. With the military retaining their political positions, therefore, Myanmar may see its first truly hybrid civilian-military government as previously excluded and marginalized entities gain access to power, though in a tenuous coalition context with the Tatmadaw. Both sides will have to accept this reality if they are committed to ensuring the state's functionality and moving reforms forward.

The NLD and Aung San Suu Kyi have been part of the formal political landscape within the legislature since the 2012 by-elections (a development which lead Senior-General Min Aung Hlaing to replace most of his junior ranked military MPs with more senior officers in an effort to ensure they continue to promote and defend the military's interests) (Egreteau, 2015a), but it is unclear if the military is willing to work with them either as equals or respect them as a majority party in the executive. This would entail, also, inclusion into security portfolios, specifically the NDSC, which while still dominated by military officers would be a major breakthrough for civilian politicians accessing one of the most secretive executive bodies in the state. The NLD, furthermore, while frustrated by the inability of the military to discuss any level of constitutional change, must work from within the current rules (even if they are biased to the military and those in power), gaining access and competencies in a host of governance issues-not least of security matters-before moving onto larger and far more contentious system-changing endeavors. Simultaneously, any civilian leadership will have to build what Larry Diamond has dubbed "negotiated packs" with the military over specific issues with the aim of building trust and mutual respect (Diamond, 2012). The military's acceptance of a smaller percentage of the budget (but still augmenting in real dollar terms) over the past few years is one example where a compromise has been made (Snaing, 2015).

The military, as well, unlike other authoritarian regime types has a legitimate and important role in the polity and, thus, continued transition does not imply the elimination of the institution but rather a (albeit comprehensive) reorganization of roles and responsibilities with the new political architecture. This will necessitate a cultural change within the officer corps of the military, one which may slowly evolve as they develop new relations with other political actors in an environment not entirely defined by hostility and mutual distrust. Indeed, the military has stripped many aspects of the political realm away from an exclusive lensing

\footnotetext{
9 Those behaviors are in apparent contravention to rules pertaining to political activities for members of religious orders as outlined in Articles 360 and 364 in the Constitution.
} 
through their national security perspective, allowing new actors and relations to populate these previously cordoned off and intensely guarded areas. Whether and under what conditions they would open up the reserve domains they have maintained, specifically security portfolios, to non-military actors in unknown but the movement away from exclusively viewing every aspect of political life as related to national security is an important step and one which may lead to further concessions over time (Callaham, 2012, p. 122).

There are many historical examples of countries transitioning away from military rule, including within East and Southeast Asia such as South Korea, Thailand and Indonesia from which lessons can be learned and applied to Myanmar (Barany, 2015; Vogt, 2014). This is not assuming the same factors in these cases are identical or transferable to Myanmar, nor that endogenous factors are not important as each case demonstrates the unique circumstances which have shaped the contours of these developments; but the overarching lesson for reformers is that, whatever the context of a transfer of power from the military, drastic and sweeping changes are inadvisable as they might provoke a countervailing reaction from the military due to what regime change means in terms of loss of power and privilege. Militaries which have transferred or in the process of ceding power, furthermore, are usually concerned with issues of status, prestige, budgets and autonomy (Barany, 2012, p. 344). For reformers a clear and transparent plan, negotiable in terms of timelines, dealing with the transformation of civil-military leaders is necessary. This allows time to develop new relations with military leaders as well as competencies in governance and security issues, earning credibility over these matters. Immediate and widespread moves for change, furthermore, may revive simpler divisions within the political landscape, transforming the discourse into a zero-sum arena in which those with significant power (and much to lose) will surely resist (MacDonald, 2014a). Even if military leaders remain committed to perpetuating their political involvement, the institutionalization of democratic structures and inclusion of other actors opens pathways for these processes to take a life of their own beyond the intents of the original architects (Morse, 2012).

Unlike other regional cases, however, Myanmar's military has ruled for much longer, becoming a far more entrenched and pervasive entity throughout the state. Economically, for example, the Tatmadaw is a large stakeholder in the Union of Myanmar Economic Holdings Limited (UMEHL) and the Myanmar Economic Corporation (MEC), two of the largest companies in the country. The dealings of the entities, furthermore, are largely unknown but it is highly suspected they are intimately related to the military's defence technologies departments, thereby being highly unlikely to release control of these organizations anytime soon (Lintner, 2013; Myanmar's Military, 2014, pp. 9-10). The Tatmadaw, however, by in large has given up control over economic decision making and accepting of a far more competitive field as the economy continues to diversify and privatize, with many of the former privileges being rescinded for the UMEHL and MEC such as tax free status (Myanmar's Military, 2014, pp. 9-10). Former military officers, though, extensively populate the economic landscape with some reports indicating Than Shwe prior to his retirement sold various state owned assets and companies to over 270 associates (Brünte, 2011, p. 17). Where there has been a retrenchment, therefore, of direct military control over aspects of the economy, these sectors are now by in large populated by former military officers and those with close relationships with the Tatmadaw, maintaining a crony capitalist system; one not as enclosed within the military institution as before but still largely removed from society and unwilling to cede their privileged positions (Jones, 2014b). While Myanmar continues to ameliorate its poor transparency and fraud regulatory mechanisms, getting the military to retrench economically, especially in extractive industries such as Jade where they hold a near monopoly, will be a long term and gradual process. 
Guaranteeing steady budget allocations and a state-run pension system, though, may motivate the generals towards divesting these economic holdings. Socially, for decades the military has been the only vehicle for upward mobility in the state, offering status, education, income and support for one's families. As Myanmar moves forward, developing opportunities and incentives in creating other mobility ladders beyond the military will be critical to diversify the state away from a reliance on the armed forces, not only as a mechanism for governance but indeed economic and social well-being (Steinberg, 2015).

Regardless of the new configuration resulting from the November election, the political system will need to resume its activities expeditiously to continue work on national level issues requiring the involvement of all major parties. These include: addressing communal violence (specifically Rohingya Muslim persecution which is increasingly having regional security consequences as thousands attempt to seek refuge by sea); ethnic ceasefires and national reconciliation; and the careful balancing of foreign relations to ensure new investment and diplomatic partners without becoming beholden to any one great power. Internationally, Myanmar must walk a careful line managing their engagements with Washington and Beijing as both are increasingly viewing one another's discourse with Naypyitaw through geo-strategic lenses (Haacke, 2012). Ameliorating and strengthening relations with Washington, which is concerned about the apparent stalling of reforms but showing no indications (or conditions) they will roll back relations, is important in expanding the diversity of Myanmar's foreign partners and coveting needed foreign investment to replace decreasing ones from China (Haacke, 2015; Sun, 2014). Beijing, which while initially caught off guard by the loss of its privileged foreign position is re-engaging in the new political dynamic, a positive sign for Myanmar as they are a necessary economic partner and arbitrator of ethnic ceasefires (Sun, 2015). These are pan-Myanmar issues which will not be solved or rectified with the immediate removal of the military. Instead, compromise and a gradualist agenda of change must become the overarching paradigm for whatever new regime configuration assumes power so that the state and society can continue to address and overcome decades of war, economic backwardness and social antagonisms.

Military intervention cannot be ruled out in the upcoming elections, but the Tatmadaw is reluctant to overtly and aggressively reintroduce themselves politically unless they feel their core interests will be irrevocably and immediately compromised by a new government. With an effective veto power over constitution, representation in the executive, and control over security portfolios, furthermore, the military may feel they can control, or at least marginalize, a civilian government and/or legislature hostile to its interests. The 2015 elections will not, therefore, mark the end of the military's preponderant political influence but will continue to erode their control over the pathways of political power and may bring about the first truly civilian-military government in the country's long transition away from military rule; a significant milestone as those outside the old, yet still influential, military regime gain access to begrudgingly-ceded power.

\section{References}

Activists Call for Replacement of Election Commission Members. (2015). The Irrawaddy.

Aung, S. M. T. (2015, January 15). The man to watch: Is Burma's top general maneuvering for a run at the presidency? Foreign Policy.

Barany, Z. (2012). The solider and the changing state: Building democratic armies in Africa, Asia, Europe, and the Americas. Princeton: Princeton University Press.

Barany, Z. (2015). Exists from military rule: Lessons for Burma. Journal of Democracy, 26(2), 86-100.

Barta, P. (2012, August 15). Myanmar appoints moderate to a key role. The Wall Street Journal. 
Brenner, D. (2014, March 17). The Tatmadaw's divide-and-rule tactics in Myanmar: Who is the ultimate target of the ongoing armed conflict? The Diplomat.

Brünte, M. (2011). Burma's transition to "disciplined democracy": Abdication or institutionalization of military rule. GIGA Working Papers.

Callaham, M. (2007). Political authority in Burma's ethnic minority states: Devolution, occupation and coexistence. East-West Center: Washington.

Callaham, M. (2012). The generals loosen their grip. Journal of Democracy, 23(4), 120-131.

Channel News Asia. (2015, January 22). Myanmar military will not stage unilateral coup.

Croissant, A., \& Kamerling, J. (2013). Why do military regimes institutionalize? Constitution-making and elections as political survival strategy in Myanmar. Asian Journal of Political Science, 21(2), 105-125.

Diamond, L. (October 2012). The opening in Burma: The need for a political pact. Journal of Democracy, 23(4), $138-149$.

Egreteau, R. (2013). Patterns of military behavior in Myanmar's new legislature. East-West Center, No. 233.

Egreteau, R. (April 28, 2015a). Military delegates in Myanmar's legislature: What do they do? What will they (continue to) do? ISEAS Perspective, No. 21.

Egreteau, R. (2015b). Emerging patterns of parliamentary politics. In D. I. Steinberg (Ed.), Myanmar: The dynamics of an evolving polity (pp. 59-88). Lynne Rienner Publishers, Boulder, CO.

Egreteau, R., \& Jagan, L. (2013). Soldiers and diplomacy: Understanding the foreign relations of the Burmese Praetorian state. National University of Singapore Press, Singapore.

Ei Ei Toe Lwin. (November 11, 2013). The army doesn't need to change. Myanmar Times.

Fisher, J. (2015, March 20). Thein Sein: Myanmar army to continue key transition role. BBC News.

Haacke, J. (2012). Myanmar: Now a site for Sino-US geopolitical competition? IDEAS Reports.

Haacke, J. (2015). US-Myanmar relations: Developments, challenges and implications. In D. I. Steinberg (Ed.), Myanmar: The dynamics of an evolving polity (pp. 289-318). Lynne Rienner Publishers, Boulder, CO.

Hlaing, K. Y. (2008). Power and factional struggles in post-independence Burmese governments. Journal of Southeast Asian Studies, 39(1), 149-177.

Hlaing, K. Y. (2012). Understanding recent changes in Myanmar. Contemporary Southeast Asia, 34(2), 197-216.

Huang, R. L. (2013). Re-thinking Myanmar's political regime: Military rule in Myanmar and implications for current reforms. Contemporary Politics, 19(3), 247-261.

Jones, L. (2014a). Explaining Myanmar's regime transition: The periphery is central. Democratization, 21(5), 1-23.

Jones, L. (2014b). The political economy of Myanmar's transition. Journal of Contemporary Asia, 44(1), 144-170.

Kean, T. (2013, February 1). Myanmar's biggest winner: The legislature. The Diplomat.

Kuok, L. (August 2015). Purge of Shwe Mann not death knell for democracy in Myanmar. Brookings Institute, Southeast Asia View.

Kyaw Phyo Tha. (2015, June 25). Parliament votes against constitutional reform, reserves military veto. The Irrawaddy.

Lintner, B. (2013, July 9). The military's still in charge: Why reform is only skin-deep. Foreign Policy.

Lwin, E. E. T. (2014, November 19). No constitution change before 2015 elections: Thura U Shwe Mann. Myanmar Times.

MacDonald, A. P. (2013a). From military rule to electoral authoritarianism: The reconfiguration of power in Myanmar and its future. Asian Affairs: An American Review, 40(1), 20-36.

MacDonald, A. P. (2013b, May 1). The Tatmadaw's new position in Myanmar politics. East Asia Forum.

MacDonald, A. P. (2014, March 14). Myanmar leaves old dichotomies behind. Asia Times Online.

MacDonald, A. P. (2015, May 27). Myanmar's military wrangle with a new political reality. East Asia Forum.

Marshall, A. R. C., \& Min, Z. O. (2013). Special report: Myanmar old guard clings to \$8 Billion Jade Empire. Reuters. Retrieved from http://www.reuters.com/article/2013/10/01/us-myanmar-jade-specialreport-idUSBRE98S00H20131001

Martson, H. (2013). Myanmar's electoral system: Reviewing the 2010 and 2102 elections and looking ahead to the 2015 general elections. Asia Journal of Political Science, 21(3), 268-284.

Martson, H., \& Morgan, A. (2015, April 8). Has Myanmar's armed forces gone too far? The Diplomat.

Min, W. (2008). Looking inside the Burmese military. Asian Survey, 48(6), 1018-1037.

Morse, Y. L. (2012). The era of electoral authoritarianism. World Politics, 64(1), 161-198.

Myanmar's Electoral Landscape. (2015, April 28). International Crisis Group, Asia Report No. 266.

Myanmar's Military: Back to the Barracks? (2014, April 22). International Crisis Group. Asia Briefing No. 143.

Myint, S. A. (2014, June 23). Electoral change motion reveals true political colors. Myanmar Times. 
Nan Lwin Hnin Pwint \& Zu Zu. (2014, December 18). Election chief under fire for raising prospect of coup. The Irrawaddy.

Nguyen, P. (February 5, 2015). Myanmar's military still a wild card as election looms. Center for Strategic and International Studies, 6(3), 1-3.

Nilsen, M. (2015, March 12). Buddhist nationalism threatens Myanmar's democratic transition. East Asia Forum.

Nilsen, M., \& Tønnesson, S. (2014). High risk of electoral violence in Myanmar. Peace Research Institute of Oslo. Policy Brief No. 6.

Not a rubber stamp: Myanmar's legislature in a time of transition. (2013, December 13). International Crisis Group. Asia Briefing No. 142.

Nyein, S. P. (2009). Expanding military, shrinking citizenry and the new constitution in Burma. Journal of Contemporary Asia, 39(4), 639-648.

Pederson, M. B. (2011). The politics of Burma's “democratic transition”. Critical Asian Studies, 43(1), 49-68.

Reuters. (2015, March 24). Myanmar to Invite Western Observers for General Election.

Schedler, A. (2013). The politics of uncertainty: Sustaining and subverting electoral authoritarianism. Oxford University Press, Oxford.

Selth, A. (2013). Burma's security forces: Performing, reforming or transforming? Regional Outlook Paper, No. 45.

Selth, A. (2015). Myanmar's coercive apparatus: The long road to reform. In D. I. Steinberg (Ed.), Myanmar: The dynamics of an evolving polity (pp. 13-35). Lynne Rienner Publishers, Boulder, CO.

Smith, M. (2015). Ethnic politics in a time of change. In D. I. Steinberg (Ed.), Myanmar: The dynamics of an evolving polity (pp. 135-157). Lynne Rienner Publishers, Boulder, CO.

Snaing, Y. (2015, January 30). Govt proposes $20 \%$ budget rise boosting education, health and defence. The Irrawaddy.

Steinberg, D. I. (2013). Burma/Myanmar: What everyone needs to know. Oxford: Oxford University Press.

Steinberg, D. I. (2014, December 13). Myanmar's militant monks smash stereotypes. East Asia Forum.

Steinberg, D. I. (2015). The persistence of military dominance. In D. I. Steinberg. (Ed.), Myanmar: The dynamics of an evolving polity (pp. 37-58). Lynne Rienner Publishers, Boulder, CO.

Sun, Y. (June 2014). Myanmar in US-China relations. Stimson Great Powers and the Changing Myanmar Issue Brief No. 3.

Sun, Y. (2015). China and Myanmar: Moving beyond mutual dependence. In D. I. Steinberg (Ed.), Myanmar: The dynamics of an evolving polity (pp. 267-288). Lynne Rienner Publishers, Boulder, CO.

Taylor, R. H. (2012). Myanmar: From army rule to constitutional rule. Asian Affairs: An American Review, 43(2), $221-236$.

Than, T. M. M. (2012). "Myanmar's security outlook and the Myanmar defence services. The National Institute of Defence Research. Japan Joint Research Series, 7, 89-102.

Than, T. M. M. (2014). Myanmar's Security Outlook and the Myanmar Defence Services.

Vogt, B. (February 2014). The path to civilian rule in Burma goes through Indonesia. Centre for National Policy.

Walton, M. (2015). Buddhism, politics, and political change. In D. I. Steinberg (Ed.), Myanmar: The dynamics of an evolving polity (p. 122). Lynne Rienner Publishers, Boulder, CO.

Weng, L. (2015, June 23). Support incumbents, Ma Ba Tha leader tells monks. The Irrawaddy. 